\title{
Shining Light on Silence: Corporal Punishment as an Abuse of Power in the Irish School System
}

Faire la lumière sur le silence : les punitions corporelles, un abus de pouvoir au sein du système scolaire irlandais

\section{Timothy Quinlan}

\section{(2) OpenEdition}

\section{Journals}

Electronic version

URL: https://journals.openedition.org/etudesirlandaises/11857

DOI: 10.4000/etudesirlandaises. 11857

ISSN: 2259-8863

Publisher

Presses universitaires de Caen

\section{Printed version}

Date of publication: 30 December 2021

Number of pages: 85-102

ISBN: 978-2-84133-157-0

ISSN: 0183-973X

\section{Electronic reference}

Timothy Quinlan, "Shining Light on Silence: Corporal Punishment as an Abuse of Power in the Irish School System", Études irlandaises [Online], 46-2 | 2021, Online since 17 December 2021, connection on 04 November 2022. URL: http://journals.openedition.org/etudesirlandaises/11857 ; DOI: https:// doi.org/10.4000/etudesirlandaises. 11857

\section{(c) (i) (ㅇ)}

Creative Commons - Attribution-NonCommercial-ShareAlike 4.0 International - CC BY-NC-SA 4.0 https://creativecommons.org/licenses/by-nc-sa/4.0/ 


\title{
Shining Light on Silence: Corporal Punishment as an Abuse of Power in the Irish School System
}

\begin{abstract}
This article focuses on one second-level teacher's experience of the use and abuse of corporal punishment in Ireland both during his own school years and during some forty years spent as a classroom practitioner. The years encompassed in this essay range from 1962 until 2018 when the author retired. The article offers a positive definition of power which is life-enhancing by way of foregrounding the gross abuse of that power in Irish schools during those years. Considerable attention is given to the rights of the child as an individual in his or her own right and the article highlights the contribution of major educationists to that end. Firmly rooted in the area of education studies, this article offers an ego-historical take on the physical and emotional bullying of young children from the early 1960s to more recent times. Acknowledging that silence in the face of any form of the abuse of power is itself consent, the author argues that any system of education worth its salt must promote a strong moral code of conduct on the part of those whom parents entrust with the education of their children.
\end{abstract}

Keywords: abuse of power, corporal punishment, rights of the child, morality, code of conduct, subversive memory, closure, healing.

Résumé: Cet article porte sur l'expérience d'un enseignant du secondaire livrant son témoignage sur la pratique et l'abus des châtiments corporels en Irlande à la fois pendant ses propres années d'école et pendant une quarantaine d'années passées en tant que pédagogue. Les années comprises dans cet essai vont de 1962 à 2018, date à laquelle l'auteur a pris sa retraite. L'article propose une définition positive du pouvoir qui améliore la vie en mettant en avant l'abus flagrant de ce pouvoir dans les écoles irlandaises au cours de ces années. Une grande attention est accordée aux droits de l'enfant en tant qu'individu à part entière et l'article souligne la contribution des grands éducateurs à cette fin. Fermement enraciné dans le domaine des education studies, cet article propose une vision égo-historique du harcèlement physique et émotionnel des jeunes enfants du début des années 1960 à une époque plus récente. Reconnaissant que le silence face à toute forme d'abus de pouvoir est en soi un consentement, l'auteur soutient que tout système d'éducation digne de ce nom doit promouvoir un code de conduite moral fort de la part de ceux à qui les parents confient l'éducation de leurs enfants.

Mots clés: abus de pouvoir, châtiments corporels, droits de l'enfant, moralité, code de conduite, mémoire subversive, tourner la page, guérison. 


\section{Introduction and a note on power}

Power is a concept that is particularly difficult to define in the abstract, one "that will be endlessly debated, contested, and continues to defy conclusive definition". ${ }^{1}$ And yet, it is especially easy to experience the positive or negative results of power in the day to day reality of our lives. We know when we are powerless in a given situation, for example. The most useful definition on which to develop my discussion of corporal punishment is that of Hannah Arendt, summarised by Joy Ann James, who defines it as

[...] communication not coercion and control: power radically differs from control, domination or violence in that it cannot be exercised over someone; it can only be exercised with others through communication and cooperation. ${ }^{2}$

Arendt's vision overlaps noticeably with what may be termed a biblical or spiritual definition. In the New Testament the term used for power is the Biblical Greek

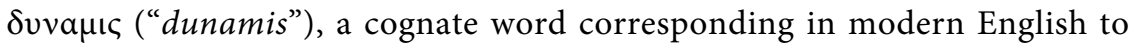
"dynamic". It connotes strength, capacity, ability, potency, force, might, and capability. The most important attribute of this biblical concept of power is its creative thrust, a dynamic that seeks to bring to fruition the potentiality of both the agent and the one acted upon. It is used some 120 times in the New Testament always in the context of acting morally in daily activities and especially in the process of healing. ${ }^{3}$ Arendt's definition shares this thrust by emphasising that power resides in and through the act of genuine communication and cooperation, two qualities that can only exist in a caring community setting. Unsurprisingly (because of its compatibility with Christianity), this constructive and relational version of power is omnipresent in the official discourses of Ireland's Catholic education system. The foundational documents of the Christian Brothers, ${ }^{4}$ in particular, present a clear and pragmatic modus operandi for the healthy use of power in the classroom

1. Jacky Lumby, "Distributed Leadership: The Uses and Abuses of Power", Educational Management Administration and Leadership, vol. 41, no. 5, 2013, p. 581.

2. Joy Ann James, "Hannah Arendt's Theory of Power as Communication: A Feminist Critique", PhD thesis in political science, Fordham University, 1987, Electronic Theses and Dissertations Collection for Fordham University, https://research.library.fordham.edu/dissertations/AAI8716208. Arendt's original text states: "Power corresponds to the human ability not just to act but to act in concert. Power is never the property of an individual; it belongs to the group and remains in existence so long as the group keeps together. When we say of someone that 'he is in power,' we actually refer to his being empowered by a certain number of people to act in their name" (Hannah Arendt, Crises of the Republic, Boston, Mariner Books, 1972, p. 143).

3. New Testament Greek Lexicon, New American Standard Version, online: https://www.biblestudytools.com/lexicons/greek. For example, in the "Parable of the Talents" (Matthew 25:14-30), the servants are given wealth based on their dunamis, or their "ability" to handle money. In general, it is a moral and creative power that enables the believer to do good, as in the following example: "We do not live the Christian life in our own power, but in God's. It is God's ability that makes us able to accomplish anything of value, for apart from Him we can do nothing" (John 15:5). In other words, we must share in God's power to accomplish anything of value.

4. See Dáire Keogh, Edmund Rice and the First Christian Brothers, Dublin, Four Courts Press, 2008. 
and the words of Irish Ministers for Education articulated these unimpeachable ideals throughout the $20^{\text {th }}$ century. Unfortunately for archive-based historians and consumers of Irish history, however, and as we will see below, these documents and words did not correspond to the real experience of power in Irish schools, and our historical vision of corporal punishment is skewed.

As its title makes clear, then, this article deals with corporal punishment as one of the most obvious abuses of power in the context of $20^{\text {th }}$-century Irish schools. Though I am developing a potentially historical narrative about a problematic past, I choose not to deploy the conventional tools of empirical-analytical historiography. Mathew Staunton and Deirdre Forde have convincingly argued that such an undertaking is always complicated by the non-existence of documentary sources. ${ }^{5}$ My training is in the fields of psychotherapy, theology and philosophy rather than history, and the last ten years of my forty-year career in education were served as a teacher and counsellor of students with Autism Spectrum Disorder. My primary concern is the human development and wellbeing of both teachers and pupils and I have opted, therefore, to adopt an interdisciplinary education studies approach, combining personal (ego-historical) insights with testimony collected via interviews with colleagues and peers, in a philosophical framework informed by psychotherapy and theology.

\section{The slow recognition of the rights of the child}

How children experience the power wielded by adults is clearly greatly impacted by the existence (or absence) of discourses of rights and by how these discourses translate via ethical and moral frameworks into action on the ground. The rights of the child arrived late on the world stage. In many countries they have not yet arrived. The recognition of universal human rights was itself a late arrival on the political scene and it took the murder and killing of millions during the Second World War for humankind to ask profound questions about justice and injustice, war crimes and crimes against humanity, about who should be the arbiters of such values and on what moral code were its proposed rights and values based. ${ }^{6}$ The international determination to answer these questions led to the Declaration of Human Rights in 1948. As regards the rights of children specifically, Polish paediatrician and revolutionary educationist Dr. Janusz Korczak had proposed a similar codification of children's rights decades earlier. ${ }^{7}$ Children's rights were

5. Mathew Staunton, Deirdre Forde, “The Room Where Nothing Makes Sense: Historiophobic Space and the Aesthetics of Child Maltreatment", in The Carceral Network in Ireland: History, Agency and Resistance, Fiona McCann (ed.), London, Palgrave Macmillan, 2020, p. 227-258.

6. There have existed numerous other codifications of the rights of citizens over the centuries from the Magna Carta (1215), through the United States Bill of Rights (1791), to the French Declaration of the Rights of Man and of the Citizen (1789) but none of them had the inclusivity, the universality, or the international legal underpinning of the United Nations declaration of 1948.

7. Janusz Korczak, Jak kochać dziecko (Warsaw, Druk. Naukowa, 1919) was not translated into English until relatively recently: How to Love a Child and Other Selected Works, London, V. Mitchell, 2018, vol. I and II, is the best edition currently available. 
neither a side project nor an appendix to the notion of universal rights. Korczak's ideas were based on his experience as a paediatrician and orphanage director rather than a reaction to the atrocities of war. Convinced of the need for action rather than good will, he imagined a declaration that would provide, among other things, for healthy living conditions, education, children's courts, and freedom from persecution. ${ }^{8}$ The (Geneva) Declaration of the Rights of the Child drafted by humanitarian Eglantyne Jebb ${ }^{9}$ and based on Korczak's ideas was eventually adopted by the League of Nations in 1924. Korczak, however, was critical of the document, finding it disconnected from the reality of children's lives. ${ }^{10}$ With the disbandment of the League, it was finally embraced by the United Nations in $1959 .{ }^{11}$

Given this slow evolution of the recognition of rights, it is not surprising that it took another thirty years for the Convention on the Rights of the Child (CRC) to be promulgated by the United Nations in 1989, a proclamation that recognised that while children are entitled to the same human rights as adults, they also have specific rights that recognise their special needs and evolving capacities. Significantly, it declared that children are neither the property of their parents nor should they ever be seen as the helpless objects of charity. They are human beings and are the subject of their own rights. ${ }^{12}$

Let us immediately acknowledge that even as late as 1989, the (quixotic) claim that Irish children were not the property of their parents was still highly aspirational rather than a statement of fact. My own teaching experience, the testimony of colleagues and maltreatment survivors, and the bulk of the academic research on the subject make it abundantly clear that for most of the $20^{\text {th }}$ century, Irish children were almost entirely devoid of the freedoms (to make mistakes, to fail, to protest, to have secrets, to own property, to live without fear) that adult citizens in Western democracies tend to enjoy in their daily lives thanks to legally binding national constitutions. The legal concepts of false imprisonment and common assault, for example, were for the most part inapplicable in the parent-child relationship, subsumed as they were into nebulous (and sometimes mythical) Common-Law notions of educational punishment and parental authority. ${ }^{13}$

8. See Betty Jean Lifton's synthesis of his ideas on children's rights in the appendix of her biography King of Children: The Life and Death of Janusz Korczak, London, V. Mitchell, 2018, p. 36-37.

9. The initial document was drafted by Eglantyne Jebb (1876-1928) a social reformer who founded the Save the Children organisation to relieve the effects of famine on children on the European continent in the wake of the First World War.

10. See Frank M. Flanagan, "Janusz Korczak and the Problem(s) of Childhood", Irish Educational Studies, vol. 21, no. 1, spring 2002, p. 57.

11. However, it was not officially signed up to by all nations until much later.

12. The full text is available on the website of the Office of the High Commissioner of United Nations Human Rights: https://www.ohchr.org/en/professionalinterest/pages/crc.aspx.

13. Ireland inherited vague common law definitions of punishment from its long legal connection with the United Kingdom. It was not until the Children Act 2004 that statuary law in England criminalised Actual Bodily Harm inflicted by parents on their children. The Children First Act 2015 abolished all residual forms of corporal punishment of children in Ireland. 
The Department of Education had very clear and (arguably reasonable) rules about corporal punishment during the $20^{\text {th }}$ century. These included:

Corporal Punishment should be administered only for grave transgression.

In no circumstances should corporal punishment be administered for mere failure at lessons.

Only a light cane or rod may be used for the purpose of corporal punishment, which should be inflicted only on the open hand. ${ }^{14}$

Up until the 1980s, however, the fuzzy logic that had long allowed often brutal assaults by parents on their children to be redescribed and defended as no more than the disproportionate use of the legitimate right to chastise a child was applied with equal force in Irish schools. Teachers and their trade unions cherrypicked the aspects of the Common Law doctrine of in loco parentis (delegating parental authority onto teachers) which allowed them to claim an automatically delegated authority to physically punish children as they saw fit without any compulsion to apply the corresponding parental duty of care. The de facto (and in Common Law, de jure) status of children as the property of their parents was therefore transferred along with all of the potential for abuse that this entailed into the hands of teaching professionals. The legal nebulousness which prevented outsiders from looking too closely at domestic violence was transferred with it and its incompatibility with the Department of Education's rules was conveniently ignored.

\section{Context}

In his 2016 article “Teachers' Experience of School: First-hand Accounts, 1943-1965” educationist Brendan Walsh builds a nuanced vision of $20^{\text {th }}$ century Irish education around a corpus of interviews of a group of retired teachers. One who was a pupil in the 1950s and 1960s recalled a "rumbling type of violence" ${ }^{15}$ in primary schools, observing that corporal punishment characterised boys' rather than girls' schools, was very focused and was principally directed at "the weak, the impoverished, the [sons of] people who would never turn up and say 'what are you doing?" ${ }^{16}$ Citing the work of the School-Children's Protection Oganisation ${ }^{17}$ Walsh states that the use of physical punishment in primary schools was "widespread and often harsh". ${ }^{18}$

14. Extract from Rules and Regulations for National Schools as Issued by the Minister for Education quoted in the appendix of SCPO, Punishment in Our Schools, Dublin, SCPO, 1974, p. 42.

15. Brendan Walsh, "Teachers' Experience of School: First-hand Accounts, 1943-1965”, in Essays in the History of Irish Education, Brendan Walsh (ed.), London, Palgrave Macmillan, 2016, p. 208.

16. Ibid., p. 212.

17. The School-Children's Protection Oganisation (SCPO) was a group of concerned parents who used the letters page of national newspapers to invite members of the public to contribute testimony to fuel a campaign to eradicate the maltreatment of schoolchildren by teachers.

18. Brendan Walsh, “Teachers' Experience of School...”, p. 212. 
These accounts are noteworthy not because they provide unusual data (they do not) but because testimony from teachers describing (or even hinting at) a level of violence that went beyond acceptable forms of punishment is extremely rare. Court records and journalistic reports of criminal and civil cases universally cite teachers justifying or denying their actions, attacking the reputations of their accusers or stubbornly maintaining that they had absolute authority to do as they pleased. ${ }^{19}$ Even retired teachers have been reluctant to question their actions or those of their colleagues and tend to defend the actions of their own childhood teachers, Walsh suggests that this is because there is a "culture of pardon" amongst teachers which prevents them from criticising their peers. ${ }^{20}$ That there was a permanent culture of violence and often extreme violence in schools across the country is convincingly evidenced by a plethora of autobiographical and witness testimony from adults recalling their childhoods. ${ }^{21}$ The point of view of teachers reflecting on their own behaviour is glaringly absent, however.

Following Walsh's lead, I choose, therefore, to treat my own teaching experience and the testimony of colleagues as source material in order to fill this gap and begin to provide material for future researchers. I will begin with two accounts from the early 1960s (contemporary, therefore, with the testimony cited by Walsh above) collected from two long-retired colleagues. One ${ }^{22}$ reported that a now well-respected entrepreneur whom he had taught in school had been so badly physically punished by a Christian brother that his parents took him out of the school after first year. Representatives of the Order had personally visited his house to apologise and beg the boy to come back with promises that nothing like that would ever happen again. The boy's parents, who were from a middleclass background, chose to decline the offer. A second retired colleague ${ }^{23}$ told me of a well-known Christian brother (a widely-acclaimed Gaelic scholar who had taught in many secondary schools) had one day knocked a boy unconscious in class with a fist to the face. Both of these accounts have been corroborated by several other witnesses.

It is clear that neither of these cases is visible to empirical-analytical historians who choose to craft their narratives around documentary sources. These incidents were never written up, no police or journalists were ever involved and the teachers in question were never formally disciplined. There are, therefore, no traces of either case in any archive. It is also clear that, despite how the teachers may have described their own actions, this is not corporal punishment as defined by the Department of Education. The behaviour of the delegation of Christian Brothers reveals that

19. See Mathew Staunton, Nathalie Sebbane, "Authority and Child Abuse in Ireland: History in a Hostile Field”, in Ireland: Authority and Crisis, Carine Berbéri, Martine Pelletier (eds.), Oxford, P. Lang, 2015, p. 135-162.

20. Brendan Walsh, "Teachers' Experience of School...”, p. 217.

21. It is necessary to entirely dismiss oral history, autobiographical accounts and survivor testimony to arrive at any other conclusion. See Mathew Staunton, Deirdre Forde, “The Room Where Nothing Makes Sense...", for a detailed discussion of this issue.

22. Interviewee A, June 2018.

23. Interviewee B, April 2019. 
they, too, were aware of this. Their attempts to persuade the middle-class parents supports Walsh's suggestion of socioeconomic prejudice. No such effort would have been invested in a working-class family.

In this article I will be reflecting upon forty years of experience in four all-male Catholic secondary schools in Dublin, spanning the years 1978-2018. The Central Statistics Office (CSO) reports that there were 100 single-sex boys schools in the Republic in 2018 with some 55,840 pupils enrolled while there were 144 mixed secondary schools with 38,698 boys on their rolls which means that $58 \%$ of all boys were educated in an all-male setting in that particular year. ${ }^{24}$ I would argue strongly that this policy of the segregation of the sexes has had and continues to have a significant effect on how power has been used and abused. There are many studies that show social and personal disadvantages of single-sex schooling. ${ }^{25} \mathrm{I}$ would argue that the all-male setting of primary and secondary schools during my time both as a pupil and a teacher led to a greater tolerance of corporal punishment until its banning by the Department of Education in 1982 and thereby provided a seedbed for the physical abuse of students both before and for some time after that date. ${ }^{26}$ Clive R. Hollin, building on a study first done by Nicki R. Crick and Jennifer K. Grotpeter ${ }^{27}$ argues that male children use physical aggression not seen in female children. Male teachers have historically also been more likely to use violence to discipline their male charges. It is also important to note that the Irish system of education during my time underwent another sea change with respect

24. See all available statistical bulletins for pupil and teacher numbers, available at: https://www.gov. ie/en/collection/annual-statistical-reports, and especially the 2019/2020 Statistical Bulletin on the same page which gives a comprehensive overview of educational statistics for the period 19992019 (July 2020). This CSO data does not give figures for years before 1998, but this does not impact on my contention here because there were more single-sex schools back then. Moreover, the Department of Education has ceased to establish single-sex schools today as there is simply no demand for such a category.

25. For example, Carolyn Jackson, Ian David Smith, in "Poles Apart? An Exploration of Single-Sex and Mixed-Sex Educational Environments in Australia and England", argue that co-educational schools foster greater social integration and maturity (Educational Studies, vol. 26, no. 4, July 2010, p. 409-422). Another study by Herbert W. Marsh, Lee Owens, Margaret R. Marsh, Ian David Smith ("The Transition From Single-Sex to Coeducational High Schools: Effects on Multiple Dimensions of Self-Concept and on Academic Achievement", American Educational Research Journal, vol. 25, no. 2, summer 1988, p. 237-269) argues that co-educational high schools provide a more natural social environment to prepare adolescents to take their place in society than do single-sex schools. The research of neuroscientist Dr. Lise Eliot argues that the claim that boys and girls should be taught in separate classrooms because their brains differ is arguably the weakest of all arguments for single-sex schooling and that students mature more naturally in a mixed setting (Lise Eliot, “Single-Sex Education and the Brain", Sex Roles, vol. 69, no. 7-8, 2013, p. 363-381).

26. Corporal punishment in schools was abolished by an administrative decision of John Boland, the Minister for Education. By 1996 its use in Irish schools had become a criminal offence. This would indicate that the government believed that its use lingered up until that time.

27. In "Relational Aggression, Gender, and Social-Psychological Adjustment", Nicki R. Crick and Jennifer K. Grotpeter maintain that girls' aggression is more relational than physical, that is, that they will show their aggression towards another by attempting to fracture their friendships (Child development, vol. 66, no. 3, 1995, p. 711). See also Clive R. Hollin, The Psychology of Interpersonal Violence, Chichester, G. Wiley and Sons, 2016, p. 5. 
to the gender breakdown of teachers in the system. In the secondary school of approximately 900 male students that I attended in the mid-1970s there were no female teachers on a staff of more than fifty teachers. The same would have obtained in all-girls schools in the 1970s.

During the period being discussed here the classroom experience for either teacher or taught had changed little between the foundation of the state in 1922 and the late 1980s as blackboards and chalk and in general a single textbook for each subject allied to traditional teaching methods still held sway. This meant, in effect, that in the classroom the teacher was absolute sovereign of their own educational kingdom and what happened in their domain generally never went beyond its walls. That period of time allowed for a more self-contained classroom that existed in isolation whereas the classrooms of the 1990s and following years were far more open due to the advent of modern teaching methods that owed much to the advances in technology and developments in architectural thinking. ${ }^{28}$ Classrooms were now no longer the private fiefdoms of the lone teacher and they were increasingly firmly rooted in a community of learning not confined solely to their own school but open to a national and international network of education through the eventual advent of the Internet.

\section{Personal experiences of corporal punishment in the classroom}

It is difficult to be one hundred per cent sure of any one memory as we have a propensity to colour our individual memories with the gloss of imagination, and sometimes even with exaggeration and prejudice, and, of course, with the strength of justified anger. I have tried over the years to be as objective as I can in interrogating memories of my professional engagement in teaching, especially with regard to disciplinary incidents and other occasional crises in which I was involved by checking with other colleagues and professionals as to what their recollection of the given situation was. In the following accounts, I have tried to be as truthful as possible, to avoid any exaggeration and have also discussed these memories with three retired secondary schoolteachers (cited as interviewees A, B and C) with 140 years-experience between the four of us.

The 1960s and 1970s in Ireland were bleak and depressing decades for families of working-class parents as wages were extremely low. When I was in primary school, class numbers often hit the high forties and even fifty mark. And the poorer the area the higher the numbers and the more necessary it was for teachers to have control of their charges. The often-intolerable conditions in which poor students had to both live and study contributed to the pressures on teachers to control their

28. See Oscar Newman, Defensible Space: People and Design in the Violent City, London, Architectural Press, 1972, for an in-depth discussion of the intimate connection between architectural design and violence. 
classes. Those teachers who were less competent and less skilled took refuge in the use of the cane or the leather strap.

In my primary school in the 1960s there were two teachers who were notorious users / abusers of corporal punishment. Their instrument of choice was the leather strap. As regards my time as a secondary school student, there was one individual, a lay man again, who was a notorious abuser of the leather and he used this right through from first year to sixth year. It did, of course, become harder for this teacher as the pupils got older and as the years passed and on occasion an enraged student would strike back. In those days the pupil would be deemed to have assaulted the teacher while the teacher would have been adjudged to have dispensed well-deserved punishment to his recalcitrant charge. The student would generally be suspended and then changed into another class to lessen the animosity. Indeed, in his later years this same teacher got several punches from irate past pupils whom he had beaten many years previously.

I began my official teaching career in 1980 and the then headmaster who was a Christian brother advised me never to hit a pupil for misbehaviour but rather to send the offender to him and that he would administer the punishment, normally three hard slaps of the leather on one hand. This brother was unusual in that he respected the rules of the Department of Education ${ }^{29}$ which stipulated that one person (generally the head teacher) in the school be designated to deal with incidents of indiscipline and administer punishment after proper investigation of the seriousness of the misdemeanour. He, therefore, did not recommend that staff use the strap or physical punishment of any kind. Notwithstanding the clear and arguably reasonable position of the headmaster, however, another Christian brother presented me with a leather strap with the instruction to use it liberally. Indeed, several lay staff also recommended that I use it until I had established myself as a teacher with good control. A colleague in a neighbouring school, ${ }^{30}$ also an all-boys, all-male teacher school, told me that their headmaster had opened a drawer in his desk with a key and had given the three new teachers in front of him a strap each with the following words: "If you can control your class, you will have a job next year. If they control you, you will have to look elsewhere for employment". This colleague described the disciplinary atmosphere in the school as simply: "Eat or be eaten". ${ }^{31}$ Colleagues who failed to keep their pupils under control were deemed "weak" teachers who lacked backbone. Indeed, in each of the four schools I witnessed at least one or two "weak" teachers who were generally described behind their backs as letting the school down and making the job harder for the stronger teachers. These teachers simply could not control their pupils in a manner that would satisfy their colleagues. It was a common perception that the negative effects of this stress could result in nervous breakdowns or heart attacks for the less resilient of these "under-performing teachers". Hence, there was considerable peer pressure on young teachers to establish

29. See the extract from the rules, cited above.

30. Interviewee D, December 2020.

31. Ibid. 
themselves. Such a system obviously allowed a bully to discipline his class in an abusive manner. From my experience of the school system, bullies were allowed to continue in their ways without any check on their teaching methodology or their methods of interaction with the students by either the school management, other staff members or the Department of Education. However, it is important to note two seminal points here: (i) the decisions of a teacher during the first half of my teaching career were considered sovereign, and no other teacher dared draw breath on how a colleague exercised their classroom management and (ii) for those years (1980-2000), the Inspectorate from the Department of Education and Skills was not very visible on the ground, as it was mainly occupied with the organisation and implementation of state examinations. However, with the setting up of the State Examinations Commission on 6 March $2003^{32}$ a renewed and vigorous inspection of education at secondary level was embarked upon and still continues. Therefore, there was really no official check on disciplinary measures for those first twenty years of my teaching experience.

One act of gross physical abuse from my first year in the profession stands out. I was teaching a first-year class consisting of thirty-nine 12 and 13-year-olds who at times could be unruly, but not in a way that could be construed as "grave transgression". One day their year-head came in and was admonishing them for their misbehaviour during a trainee teacher's class. He said that if he had his leather strap with him, he would give them all "six of the best". At the time I had a leather in my bag (the one I had been given when I had started teaching some months previously) and at his request, as a very sheepish new teacher, I handed him the instrument of punishment and he proceeded to wildly swing at the outstretched hands of all thirty-nine pupils, leaving them blowing on their burning palms and running them under the water tap to attain some relief. From that day on I had an abhorrence of both the use and abuse of corporal punishment as a means of behavioural correction. ${ }^{33}$

A second example which further illuminates the darker corners of the abuse of power through corporal punishment is an encounter I had with a deputy principal, when I had changed school and taken up a new teaching post in 1988. He drew me to one side and declared that if I had any trouble with any boy in the school that I should take him into a small interview room and give him a good hiding, and that if his parents protested it would be my word against their son's. ${ }^{34}$ Again,

32. The Commission assumed responsibility for the operation of the State Certificate Examinations from the Department of Education from 2003 onwards and freed up personnel to focus on the running of schools.

33. In my own case, I used the leather strap twice, and on both occasions, I found that it not alone dehumanises the victim but also the one who uses it. On the second occasion I managed to hit my own thumb, blackening the nail. After that, I never used it again, seeing the black nail as a fitting emblem of the immorality of a very dark and sinister practice. I believe I left the offensive instrument of punishment on a table in the staffroom never to see it again.

34. See Mathew Staunton, Deirdre Forde, “The Room Where Nothing Makes Sense...”, for a similar account. 
I was startled at such an approach to discipline by so-called professional teachers from the era before mine. The individual in question was also a bully to the weaker members of staff whose standing before colleagues and pupils he would undermine relentlessly. He was an outlier on the staff all his life for his outrageous behaviour. Such amoral and violent teachers can no longer exist within the education system in Ireland in the $21^{\text {st }}$ century as there are far more rigorous state and Board of Management controls in place, and a teacher is answerable to both and can be struck off the register of teachers for malpractice and tried before the law for a criminal offence. A past pupil ${ }^{35}$ of the school, now in his 40 s and with a young family, recently recalled how as a 12 year-old he had been consistently humiliated before the class by this same teacher who would bring him up to the blackboard to do a mathematical problem and punch him if he made a mistake, while at the same time abusing him verbally. Significantly, the man attributes his current low self-esteem and chronic anxiety to his maltreatment by this teacher, whom the system failed to control or discipline.

The social and moral teachings of the Roman Catholic Church and the laws of the state, while arguably ethically sound in principle, were in large measure simply ignored by church and state when it came to issues of corporal punishment and other areas of the abuse of children. To put this contention in religious terms, both the leaders of these institutions sinned more by "omission" than "commission". ${ }^{36}$ In other words, it was largely their failure to act morally, indeed their failure to act at all in certain circumstances and to ignore and cover up acts of gross immorality by certain of their members that allowed corporal punishment and sexual offences to occur and to continue unpunished. Most teachers, during the first two decades of my teaching career went about their work without giving the slightest consideration to how their fellow professionals managed their classes. Such blithe indifference changed suddenly with the revelation in the 1990s of the covering up of sexual scandals that had obtained in the Catholic Church for many years. ${ }^{37}$ No more could education remain imprisoned in a closed circuit of restricted and often biased knowledge. My experience on the ground was of a transformation of teaching from an individual and isolated activity to one that was fast becoming a community-based enterprise where the teacher was now part of an ever-expanding network of teaching and learning at school, national and international levels with many tendrils stretching into a globalised world of information and knowledge freely available to all.

35. Interviewee E, February 2020.

36. This differentiation of sin in Christian moral teaching dates back to the composition of the New Testament, and is not solely a Roman Catholic tenet but is one shared by all Christian churches and is based on such New Testament texts as James 4:17, "therefore, to one who knows the right thing to do and does not do it, to him it is sin".

37. Much has been published on this subject in the last three decades. A nuanced overview can be found in Marie Keenan, Child Sexual Abuse and the Catholic Church: Gender, Power and Organizational Culture, Oxford, Oxford University Press, 2012. 


\section{Silence is consent}

Father Shay Cullen, winner of the Human Rights Award from the City of Weimar (2000) and the Martin Buber Prize for Dialogue (2017) for his work to fight the sexual exploitation of women and minors in the Philippines has repeatedly argued that "silence is consent to abuse", and has followed that principle in his daily life for years. ${ }^{38}$ This statement cuts to the heart of the matter and avoids the tortured twisting of language by way of invented excuses. Moreover, it is at once a salutary statement and a sharply aimed barb at the majority of us who find it hard to rock the boat. ${ }^{39}$ Cullen has lived, consequently, under the fear of death threats for most of his life. Silence as consent is an ancient principle that stretches back to Roman law and it is a maxim that Robert Bolt in his drama A Man for All Seasons places in the mouth of his hero Sir Thomas More with regard to his silence on the Act of Supremacy (1534), a maxim which unfortunately backfired on More as the King and his Chancellor Thomas Cromwell interpreted it as dissent:

The maxim is "Qui tacet consentit": the maxim of the law is "Silence gives consent". If therefore you wish to construe what my silence betokened, you must construe that I consented. ${ }^{40}$

This maxim has grave implications for all of us. Our silence proclaims our consent to many injustices. Indeed, our knowledge of injustices and often-ignored crimes of all sorts betokens our acceptance and consent. We often forget, unconsciously and sometimes deliberately, that all knowledge comes with an ethical consequence for us and, for the most part, we are content to keep our heads down and take the path of least resistance. Few are brave enough to become whistle-blowers or conscientious objectors. To do so often results in initiating one's own downfall, with the possible impoverishment of one's family as a consequence. Such action generally results in major psychological stress on individuals and their families and, in extreme cases, can lead to suicide or murder. And so, from psychotherapeutic and philosophical perspectives, I wish to ask the following question: "Where and when do I consent to injustice by my silence?". It is far too easy to point to the flaws of others whilst ignoring "the beam in my own eye". ${ }^{41}$ Therefore, I turn to an analysis of the ethical grounds for our discussion of the abuse of power.

38. A succinct account of his position can be found in the following article by Shay Cullen: "A Silence That Is Consent to Abuse", The Manila Times, 23 October 2016, online: https://www.manilatimes. net/2016/10/23/opinion/analysis/silence-consent-abuse/292640.

39. Cullen set up an organisation called PREDA (People's Recovery, Empowerment and Development Assistance), a small non-profit operation that has a number of purposes, the most important of which are the promotion and protection of the human rights of the Filipino people especially women and children whom he and his colleagues seek to protect from sexual slavery.

40. Robert Bolt, A Man for All Seasons, London, Bloomsbury, 2013, Act 2, the trial scene, More's answer to his cross-examiner Thomas Cromwell, p. 59.

41. This is a verse from Matthew's Gospel (Matthew 7:5). The full verse runs: "You hypocrite! First, remove the beam out of your own eye, and then you can see clearly to remove the speck out of your brother's eye" (The World English Bible). 


\section{The disempowered conscience}

Ethics is a system of moral principles which affect how people make decisions and lead their lives. Let me first make a distinction between "ethics" and "morality". The first term refers to an external, objective codification of behaviour by society and its professional institutions while the second refers ultimately to an individual's personal compass of right and wrong, namely how they have internalised the rules set down by society and its institutions. Ethics and morals are concerned with what is good for individuals on the one hand and society in general on the other. ${ }^{42}$ Here lies one of two major ethical concerns for my discussion of the abuse of power as oftentimes what is good for one might conflict with what is good for the other. The second ethical concern, inextricably bound up with my subject, is the balancing of the age-old distinction between rights and responsibilities. ${ }^{43}$ Incidentally, the clouding of this important distinction was the major criticism Korczak made of the 1924 Geneva Convention of the Rights of the Child: "The Geneva law-makers confused duties with rights; the tone of the declaration is one of persuasion not insistence: an appeal to goodwill, a plea for kindness". ${ }^{44}$

Sociologically, an institution refers to a "large-scale social arrangement that is stable and predictable, created and maintained to serve the needs of society". ${ }^{45}$ Education is one example of such institutions, and the family another. These social organisations carry great authority and with them come strong ethical guidelines. ${ }^{46}$ My experience of the school system has been that of the overriding strength and rigidity of the institution of education as it impacted on me as an individual teacher within that system. As a young teacher, I was overawed by that strength and rigidity which, like my many colleagues, I very seldom questioned. We were happy to have a job and an income and to get on with our lives. The time or the energy required to question the system were beyond our quotidian and indeed selfish concerns. In this sense, when we become either full-time or part-time workers within an institution, we of necessity become unconsciously part of the very fabric of that institution and subscribe equally unconsciously to its culture on the ground, whatever official policy documents we may have signed and consciously subscribed to ethically. In short, the rights and responsibilities of the individual are subsumed, indeed eclipsed, by the overriding power of the

42. Enda MacDonagh stresses this point in Gift and Call: Towards a Christian Theology of Morality, Indiana, Abbey Press, 1975, passim.

43. The Greek philosopher, Aristotle, stressed that to every right there was a corresponding duty or responsibility. He stressed this point often in both his Nicomachean Ethics and his Politics.

44. Quoted in Frank M. Flanagan, "Janusz Korczak and the Problem(s) of Childhood", p. 52.

45. Definition given by the Open Education Sociology Dictionary, https://sociologydictionary.org/ institution

46. Article 41 of Bunreacht na hEireann recognises the family "as the natural primary and fundamental unit group of Society", and as a "moral institution possessing certain inalienable and imprescriptible rights" which are "antecedent and superior to all positive law". The state guarantees to protect the family in its constitution and authority "as the necessary basis of social order and as indispensable to the welfare of the Nation and the State" (Constitution of Ireland, article 41.1.2). 
institution. In other words, we set our consciences to one side where they become much disempowered through lack of use. Carl Jung argued that human beings conform to the "herd mentality" because "thinking is difficult" and judging and pointing the finger so easy. ${ }^{47}$ I conclude that our failure to protest against injustices of all kinds, as well as corporal punishment and child abuse, may be written down among other reasons to our laziness, our indifference and our basic selfishness as well as our gross lack of courage. However, there are of course other mitigating circumstances like genuine fear for our progress in life and for the future of our families. In sum, let us not make the mistake in our analysis of the abuse of others either locally or globally that any moral situation that confronts us is simple. Like truth itself, reality is neither simple nor pure. Life is extremely complex and suffering is an inherent part of it existentially. ${ }^{48}$

The second point I stated above is also very important to the question of the abuse of vulnerable children being discussed here, namely that to every right we loudly proclaim there exists an equal imperative on us to protect the rights of others by acting responsibly. It is all too easy to declare loudly our rights while neglecting our duties to protect those of others. We are constantly being taught by the atrocities and injustices of history that we are members of a community more than simple individuals as we exist in connection with others, with communities, with nations and indeed with humanity in general, all of which define us. I am responsible, therefore, (i) for myself, (ii) for others who are dear to me, (iii) for all others with whom I share community and finally (iv) for the world of which we humans are but one creature among many. And so, when I reflect on the abuse of corporal punishment, if I have stood idly by when such was being perpetrated on another, I have shirked my responsibility.

These two points, then, explain in general the failure of individuals to act against injustices that lie under their very noses. They also explain my own personal failure to act when I should have over the years. None of us can ever escape responsibility by protesting either our ignorance of what was happening or that we were only doing our duty like our fellow workers. While we might unthinkingly point our finger at the failure of others to act and at their apparent culpability in X or $\mathrm{Y}$ action or inaction, we often forget that another three fingers on that hand point irrevocably back at ourselves. This is what Dostoevsky essentially meant when he

47. The full quotation runs: “Thinking is difficult, therefore let the herd pronounce judgment!" (Carl Jung, The Collected Works of C. G. Jung, vol. X, Civilization in Transition, Sir Herbert Read (ed.), London, Routledge, 1970, p. 344).

48. It is a central principle of practically all approaches to psychotherapy, especially that of the existential variety, that suffering and death are ineluctable and central aspects of the human condition. The implication of this central principle is that one of the functions of all therapy, and indeed of all good education, is to equip clients or students respectively with skills to cope with the problems and conflicts with which death and suffering present each and every one of us as human beings. See especially Irvin Yalom, Existential Psychotherapy, New York, Basic Books, 1980; and Gerald Corey, Theory and Practice of Counseling and Psychotherapy, $7^{\text {th }}$ ed., United Kingdom - United States, Thomson - Brooks/Cole, 2005. 
declared that "all are guilty before all and for all" ${ }^{49}$ and that there is no gainsaying that we are, in fact, our brother's and our sister's keeper.

\section{Unfinished business}

"Unfinished business" ${ }^{50}$ is a term commonly used in therapy, especially in Gestalt ${ }^{51}$ circles. It is a phrase therapists use to describe the emotions and memories surrounding past experiences that a person has deliberately avoided or repressed. Many ageing Irish adults, the majority males due to the prevalence of male-on-male violence, who went to school prior to the abolition and eventual criminalisation of corporal punishment suffer from post-traumatic stress disorder (PTSD) as a result of their being physically abused in the school system. As recently as 2018, in a report in The Irish Times, Kitty Holland, the social affairs correspondent, interviewed eight men and two women, ranging in age from early 1960s to mid1970s. Her report bears witness to what can be described as a reign of terror against the most vulnerable in the population, namely poor, working-class children. The article describes a litany of abuse and sums up the psychological price paid by these damaged souls in the words of one of the interviewees: "My childhood was stolen". ${ }^{52}$ There are many other people who are silent sufferers and whose pain and humiliation remain undocumented from the era of corporal punishment I am describing in this article. ${ }^{53}$

49. Quoted in Geir Kjetsaa, Fyodor Dostoyevsky: A Writer's Life, London, Macmillan, 1989, p. 348. It is of no little interest in the context of the present essay that Dostoevsky protested strongly against the maltreatment of children both in his considerable journalistic output and in his novels. For instance, he deals specifically with an atrocious case of the severe corporal punishment by Lieutenant Stanislav Kronenberg of his daughter, a case which was tried in court in Moscow in February 1876. Dostoevsky discussed that landmark case in his Diary the same month. The character Ivan in The Brothers Karamazov (1878-1880) uses a similar scene of the brutal maltreatment of a little girl as a strand in his argument against the existence of God.

50. Unfinished business persists until the individual faces and deals with unexpressed feelings of rage, grief, anger, pain, anxiety and so on. See Gerald Corey, Theory and Practice of Counseling and Psychotherapy, p. 196-197.

51. The German term "Gestalt" translates as "form", "shape" or "pattern". The Gestalt approach to therapy was developed by Fritz Perls and his wife Laura in the United States in the 1940s and 1950s. They followed the definition of the "gestalt" method given by German psychologist Kurt Koffka: "The whole is other than the sum of its parts". This word "other" in this definition was / is often inaccurately rendered in English as "whole" (see Fritz Heider: The Notebooks, Marijana Benesh-Weiner (ed.), New York, Springer Publishing, 1988, vol. III, p. 300-301). The overall Gestalt approach is to focus on the integration of disowned parts of the self (parts that are hidden for fear of rejection) and consequently nothing "unfinished" or denied or supressed should be ignored by either the client or the therapist.

52. Kitty Holland, "Beaten: The Irish Childhoods Ruined by Corporal Punishment", The Irish Times, 29 September 2018.

53. See Mathew Staunton, Deirdre Forde, “The Room Where Nothing Makes Sense...”, for a discussion of this issue. 


\section{Subversive memory}

There is a strong and effective tradition in liberation theology ${ }^{54}$ called, challengingly, "subversive memory". ${ }^{55}$ Such memory, theologians like Jon Sobrino, SJ see as a clarion call to view injustice and oppression with the clear eyes of the victims and not through the prism of the eyes of the powerful who would wish to show such abuses of power in a more agreeable light. ${ }^{56}$ Therefore, it would be no little act of justice on our part to embrace such a call to subversive memory with respect to abusive corporal punishment which was, by the powerful witness of those who suffered under its cosh, a reign of terror against the most vulnerable in our society. By applying Sobrino's principle, then, we should try as far as possible to see issues through the eyes of the victims. One can easily point to the example of Catherine Corless, the Irish local historian, known for her work in compiling the information concerning the deaths of children at the Bon Secours Mother and Baby Home in Tuam, Galway as a good example of a commitment to subversive memory. In short, such a commitment challenges the accepted institutional view which, of its nature, is centripetally focused on self-preservation over truth. What are needed, then, are investigative journalists and uncompromising historians to work with those physically and emotionally abused to spark the subversive memory into action with regard to historical corporal punishment in Irish schools. ${ }^{57}$

\section{Conclusion: towards closure}

In a timely and wise contribution to this debate, Professor Pat Dolan, director of UNESCO Child and Family Research Centre, National University of Ireland, Galway recommends the establishment of "some form of truth commission" 58 to

54. Liberation theology is a Christian theological approach emphasising the liberation of the oppressed, often engaging socioeconomic analyses and addressing contexts of inequality such as race or caste.

55. A subversive memory is one that summons us to view the world with the clear eyes of victims, not through the prism of the powerful, as such a prism can be rotated to show things in a more agreeable and most often unjust light. In the present context, it summons us to look at the issue of corporal punishment through the eyes of the children so abused in order to take their testimonies seriously. Such an exercise is a moral one as well as being a highly imaginative one as we have to place ourselves in the position of the victims and attempt to see the world from their viewpoint.

56. Jon Sobrino SJ, born in Barcelona of Basque roots, is a prolific writer in the fields of theology and spirituality with a distinctive liberation theology approach grounded in the rights of the oppressed. He spent much of his life in El Salvador where he witnessed much violence and oppression against the poor as well the murder of five of his religious confreres. Like other liberation theologians he has incurred the censure and condemnation of the Roman Curia for what they erroneously believe to be a Marxist emphasis in their theology.

57. The collection and diffusion of testimony from the survivors of Ireland's Magdalene Laundries provide an excellent model for this work.

58. Pat Dolan, "Unfinished Business: Corporal Punishment in Irish Schools”, RTÉ Brainstorm, 19 October 2017, online: https://www.rte.ie/brainstorm/2017/1019/913515-unfinished-businesscorporal-punishment-in-irish-schools. 
allow the adult victims of historic corporal punishment to give expression to their traumatic experiences at the hands of irresponsible and sadistic teachers. His call was made over two years ago and to date no official action has been taken on either setting up counselling for these silently suffering souls, much less the organisation of a truth commission. ${ }^{59}$ However, there is much else that can be done by those involved in teacher-education, childcare provision and youth work - such as the strict interviewing of and personality-testing of prospective workers in these areas to check that they are really suited to the task. Furthermore, continuing professional development (CPD) in the area of effective communication and the rights of children is always necessary. Quinlan remarks that "the complex questions of authority and discipline can only be understood and tackled within an overall commitment to both professional and self-development on the part of the teacher".${ }^{60}$ Moreover, in line with such development, the most important thing we human beings should be taught is to reflect upon our often-unconscious use and abuse of power as we interact with one another. In this task, the promotion of solid philosophical skills like questioning our own presumptions and motives, asking robust moral questions about our own actions and, indeed, inactions, engaging in shared debate on the issues of power and control in our engagement with students at classroom level are all healthy actions in which professional educators at all levels should engage. Such analyses of our own presuppositions, actions and inactions should lead to the exposure of prejudices that should be squashed before they grow out of control and unchallenged in the school setting. In the notion of power adumbrated by Arendt the fostering of a strong community of learning must be actively promoted. This is an association of learning where leadership is both decisive and encouraging and never overwhelming and autocratic. Real discipline or control is a community enterprise, exercised and administered with care and insight and willingly accepted by the vast majority of students as just and legitimate. Such a community of learning is also one where both teacher and student are liberated to develop and express both formally and informally the best version they can possibly be of themselves, buttressed by the sound educational philosophies of educationists and philosophers such as Janusz Korczak, Martin Buber and Paulo Freire.

Korczak established in his orphanage a "republic for children" with its own small parliament, law-court and newspaper thereby respecting every child as a unique and responsible individual who could contribute much to society. ${ }^{61}$ Martin Buber saw education as essentially dialogical, where the teacher treated the student as a unique other (a "thou") worthy of respect and not as a container (an "it") to be filled with knowledge. Furthermore, the role of the teacher was that

59. The issue of corporal punishment for girls was raised in the Senate by Dr. Sheehy Skeffington in 1956. See debates online: https://www.oireachtas.ie/en/debates/debate/seanad/1956-04-19/6.

60. Timothy Quinlan, “Authority, Discipline and Self-Discovery”, Issues in Education, vol. 3, 1998, p. 140.

61. See Adir Kohen, The Gate of Light: Janusz Korczak, the Educator and Writer Who Overcame the Holocaust, London - Toronto, Associated University Presses, 1994, p. 260 and following. 
of an authentic educator who sought to allow students develop the best version of themselves through both pedagogical and caring interventions in their learning. ${ }^{62}$ Paulo Freire saw the main purpose of education to be the "conscientisation" of students, developing in them a critical consciousness that would lead them to realising their own oppressed situation and to act constructively to bring about their liberation from all forms of oppression. ${ }^{63}$ For real power to reign in an educational setting, it has to be rooted in a community of teaching and learning where communication and cooperation are its hallmarks. Such a community will never be one that could possibly allow, much less tolerate, the barbarity of physical abuse that obtained in Irish schools prior to the 1990s. With respect to the suffering of Irish victims of abuse, much unfinished business remains to be dealt with, so that some healing can be achieved. Finally, we can but hope that there will be an open and sincere acknowledgement of both the individual and collective guilt of many with respect to this silently weeping wound in the history of Irish education. Only then will some closure have been achieved at last for these long-suffering individuals who endured much pain at the hands of misdirected and cruel individuals appointed to such positions of power by both a negligent church and a heedless state.

Timothy QuinLAN

Dublin City University

62. See Daniel Murphy, Martin Buber's Philosophy of Education, Dublin, Irish Academic Press, 1988, for a concise introduction to Buber's educational thought.

63. Conscientisation is the process of developing a critical awareness of one's social reality through reflection and action. Action is fundamental because it is the process of changing the reality. See Paulo Freire, Pedagogy of the Oppressed, Myra Bergman Ramos (trans.), Harmondsworth, Penguin, 1977 , p. 1-20. 